\title{
ANALYSIS OF A SELECTED MOTORBIKE SUSPENSION COMPONENT WITH THE USE OF CAD MODELLING AND FINITE ELEMENT METHOD
}

\begin{abstract}
Modelling procedure as well as structural and modal analyses of high-performance motorbike suspension element are presented in this article. Siemens NX 8.5 system has been used while preparing CAD model of components. The numerical analyses have been performed based on Finite Element Method (FEM) in ANSYS Workbench package. The behaviour of the considered part that reflects its working conditions has been set by defining appropriate loads, boundary conditions and design assumptions. As a result of the performed analyses, stress and strain distributions as well as selected natural vibration modes have been received. On the basis of these results the conclusions and further research directions have been formulated.
\end{abstract}

Keywords: CAD, CAE, structural analysis, modal analysis, finite element method

\section{Introduction}

High-performance motorbikes of the cross/enduro class are the most popular among these who prefer dynamic ride style. Only driving skills and high quality of the used equipment can ensure safe and controlled entertainment. Motocross is an extreme style of driving that does not accept technical barriers, thus the whole vehicle structure has to fulfil high performance requirements.

Tough competition on the market as well as demanding clients' expectations enhance the development of moto disciplines. Products of a good quality should ensure their reliability during their exploitation. Theoretical design calculations and many destructive tests had to be performed to meet requirements for reliability on the real components in the past. Each trial engaged a bunch of expensive hardware or supervisory personnel what made the procedure not only inefficient, but also cost and time consuming.

Over the last decades the development of IT technologies has led to the improvement of engineering discipline. As a result, highly advanced CAD and

\footnotetext{
1 Autor do korespondencji/corresponding author: Tomasz Bik, Rzeszow University of Technology, al. Powstańców Warszawy 8, 35-959 Rzeszów, tel.: 17865 1318, e-mail: tomek.bik@gmail.com
} 
CAE tools are regularly utilised during design/redesign processes. The use of CAD and CAE tools limits to a minimum real assembly and fatigue trials. In fact, most of them is performed virtually based on the CAD models but with an accurate reflection of the boundary conditions. Popularity of CAD and FEM is confirmed by various scientific studies in this subject, e.g. [3, 4, 8-10]. The ability to simulate the real working conditions makes CAD/CAE systems an effective tool that support the durability analyses of mechanical structures not only for automotive $[5,7]$ but also aviation industries $[2,6]$. They are successfully utilised in numerous scientific investigations.

\section{Scope of the analysis}

A motorbike suspension arm is a frame-coupled component that maintains rear wheel in its working position. It is a rigid element with the ability to rotate against frame. Damping module is consisted of a suspension arm and shock absorber. The main function of this module is to reduce strikes and vibrations.

New generation of motorbikes are equipped with suspension arms made of high-strength cast alloys. Better mechanical properties of the utilised material directly affect the final component price. Therefore, there exist cheaper substitutes in the market. An example of such a substitute dedicated for motorbikes CROSS 125, 150 and 250 series is shown in Fig. 1.

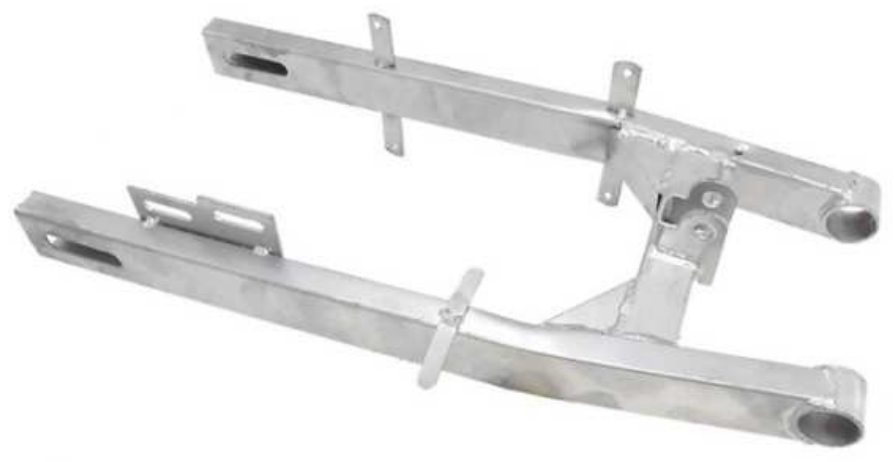

Fig. 1. Rear suspension arm substitute for motorbikes CROSS 125, 150 and 250 series

Due to exposure on strikes and large loads, each suspension element appears to be a critical component. Therefore, the suspension arm has to be characterised by high reliability and mechanical strength. 


\section{Objectives of the study}

The first objective of this study is to present some selected features of CAD/CAE environments. Thus, a CAD \& FEM design is discussed (e.g., different element types and sizes). The second aim is to confirm proper functionality of the suspension arm within chassis structure and defined design boundaries. To prove the lack of negative influence of component on its safety, thus some structural analyses were carried out.

Modelling issues, strength of the structure under static load as well as natural frequency analysis are the main scope of this paper. The application of a cyclic load, component's fatigue strength and vibrations with unsteady excitation will be investigated in the future. Based on the complete analyses, some conclusions to the existing geometry will be formulated.

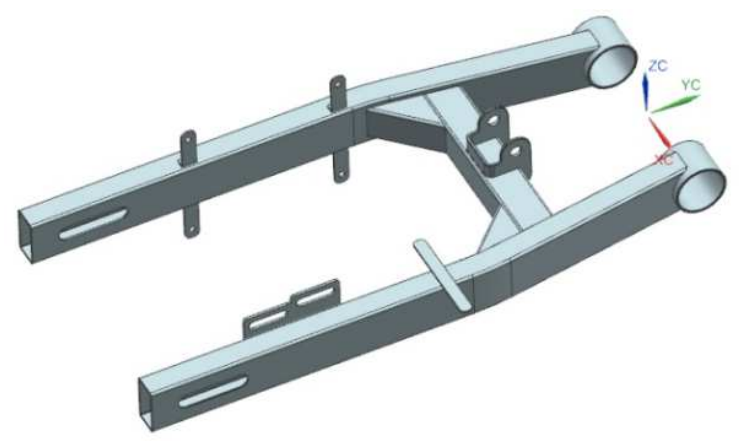

Fig. 2. 3D CAD model of suspension arm

\section{CAD model}

The dimensions of CAD model of suspension arm are corresponded to the characteristic dimensions of the real component. Some standard measuring instruments (e.g., a calliper, a ruler, etc.) have been used to measure the analysed part. Then the 3D model of structure (Fig. 2) has been generated using NX 8.5 system. The model is symmetrical, so there was no need to model a complete component.

Parametrical dimensioning has been applied while sketching. The main goal was to prepare a few alternative design concepts in a simple way, e.g. different wall thicknesses, bushing sizes or lugs lengths. In comparison to standard modelling approach, parametrical dimensioning allows to analyse different variants that can be dedicated to some motorbike versions. The model reflecting the performed measurements has been selected for further FEM analysis.

Basically, a detailed CAD geometry leads to difficulties with proper mesh quality. A huge amount of mesh elements increases the computation time. Thus, 
CAD model was simplified so that calculation time could be optimised. As a consequence, small mass elements not affecting structural aspects (bearers for shields, brakes or brake cable brackets) have been omitted in the calculations (Fig. 3). Similarly, edge roundings and weld joints geometry were not considered. The CAD model (*.igs file) was exported to FEA system (ANSYS Workbench) requirements.

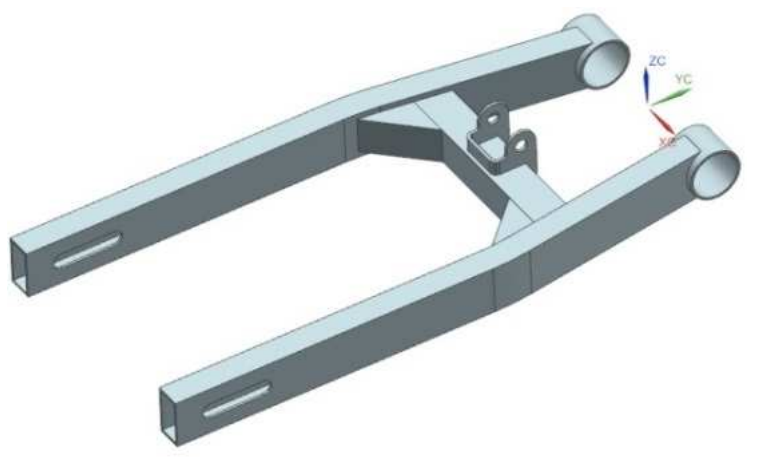

Fig. 3. Simplified 3D CAD model of suspension arm

\section{Finite element analyses}

Modeling in FEA system starts from setting a new project and choosing desired types of analysis (Structural Analysis, Modal Analysis). In the next step the CAD geometry has been imported to FE model. The units have defined as metric. The material properties of constructional steel were as follows: Young's modulus $2 \cdot 10^{5} \mathrm{MPa}$, density $7850 \mathrm{~kg} / \mathrm{m}^{3}$, Poisson's ratio 0.3 , and yield point $250 \mathrm{MPa}$. Then one of three available computational models had to be selected:

- solid (Solid Body),

- surficial (Surface Body),

- linear (Line Body).

The chosen model determines the type of geometry that is used during analyses (e.g., solid or shell). Solid Body option has been selected to model a suspension arm. Although Surface Body model has been taken into consideration as well. Proper calculations depend on appropriate definition of boundary conditions and loadings. These parameters should reflect real element behaviour during its operating. The rigid construction movements (global shift or rotation) [1] causes that boundary conditions are not defined sufficiently. This leads to numerical singularities, computation failures or large, uncontrolled structure displacements. On the other hand, too restrained displacements of the analysed component or assembly (e.g., due to rigid instead of movable constrains) lead to over-constraining of the model and cause computation failures in form of local stress concentrations [8]. So, the concentrated forces or momentum loadings should not be applied to a solid body. 
Having in mind all these remarks, import and proper model orientation within working space and Global Coordinate System (GCS) has been accomplished. Two additional coordinate systems have been defined:

a) UW1: OX1 axis covers centres of the shock absorber mounting holes, OY1 points forward direction,

b) UW2: OX2 reflects position of the rear wheel axle mounted in lugs, OY2 points forward direction.

To define boundary conditions some degrees of freedom have been removed in model of the analysed component. Thus, free linear movements in $X$, $\mathrm{Y}$ and $\mathrm{Z}$ directions have been locked by fixing cylindrical surfaces of the bushes. Simultaneously, free rotation condition around axes OX and OX2 have been established so that the structure is able to bend and deform. Constraint of constant distance between lugs and frictionless supports at the end of the lugs' were defined using Frictionless Support option).

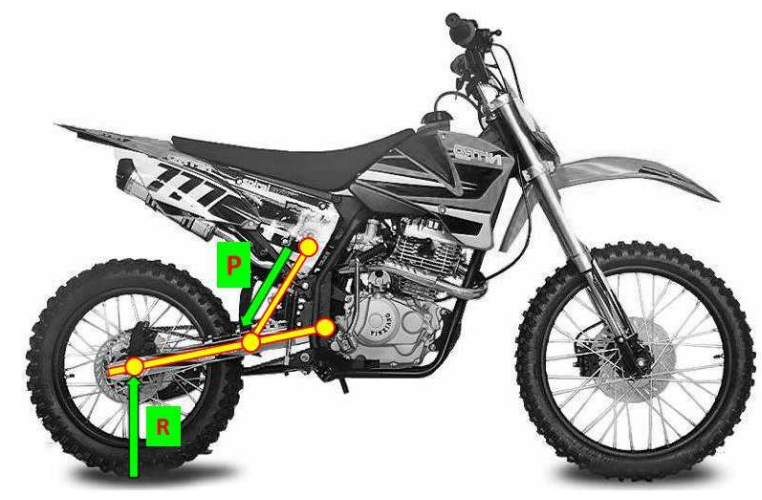

Fig. 4. Loading vectors layout

Definition of the static structural analysis assumes that mass of the vehicle $(80 \mathrm{~kg})$ and mass of a driver $(90 \mathrm{~kg})$ are the key load sources. It was also assumed that rear wheel is loaded with $60 \%$ of the total mass load $(\sim 100 \mathrm{~kg})$. The safety factor was equal to $k=1.4$. The resulting reaction force (Fig. 4) acting on the motorbike wheel was established as $\mathrm{R}=1400 \mathrm{~N}$. Load vectors are illustrated in Fig. 5. The force $\mathrm{P}$ that acts on suspension arm strut can be calculated according to Eqs. 1-3 (Eq. taking into account that:

$$
a=0.138 \mathrm{~m} \quad b=0.440 \mathrm{~m} \quad R=1400 \mathrm{~N}
$$

Momentum equality condition:

$$
M_{A}=0
$$

$$
-R * \cos 15^{\circ} * b+P * \cos 30^{\circ} * a=0
$$




$$
P=\left(R * \cos 15^{\circ} * b\right) /\left(\cos 30^{\circ} * a\right)
$$

Then $P=\frac{1400 * 0.966 * 0.440}{0.866 * 0.138}=4979 \mathrm{~N}$

where: $R 1=R 2=\frac{1}{2} R$ (single arm loading)

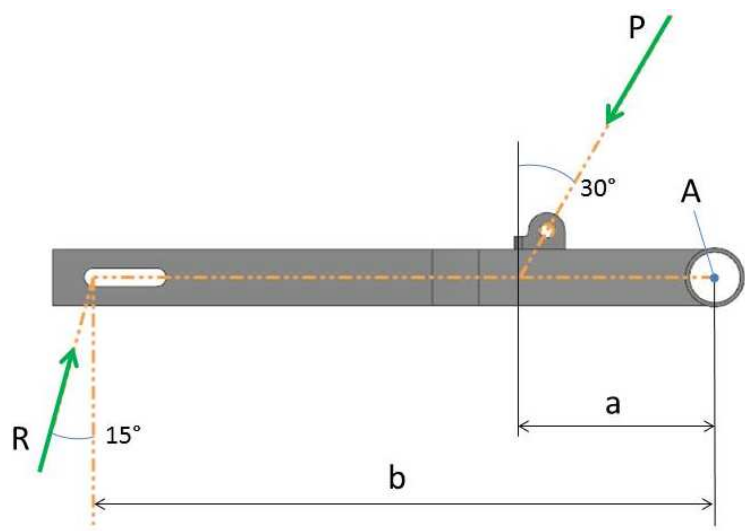

Fig. 5. Load vectors $(\mathrm{P}-$ load resulted from total mass of both vehicle and driver, $\mathrm{R}$ - ground reaction acting on the rear wheel, $\mathrm{A}$ - front bushes centre, $\mathrm{b}$ - distance between OX and OX1 axles, $\mathrm{a}-$ arm for projected force $\mathrm{P}$ )

To keep mesh elements free of stress concentrations, load have been expressed as pressure acting on surfaces fragments. Hence the cylindrical surfaces of holes in strut have been halved (faces 1 and 2 in Fig. 6) as well as wheel axle contact areas have been defined as small rectangular surfaces (faces 3 and 4 in Fig. 6). To generate them, Split Face tool within Mechanical Engineering module is be used.

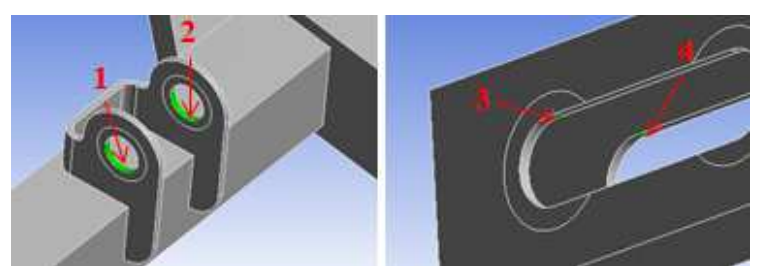

Fig. 6. Faces loaded with pressure

Mesh quality is strongly influenced by accuracy of the mapped model geometry (Fig. 7). It determines precision of the final solution as well as total 
computational time. The best results of analysis were achieved for regular and ordered cubical higher-order elements [11]. Deviations of the model in the form of bevels or elongated mesh elements negatively influence the results of analyses. Models with complex geometry are usually meshed using tetrahedral elements (10-node higher-order elements). Despite that these elements reflect the geometry more accurately in comparison to 20-node elements, there appeared some loses in calculations precision. Therefore tetrahedral higher-order elements appear as a compromise to tetrahedral 4-node linear elements (the least accurate results).
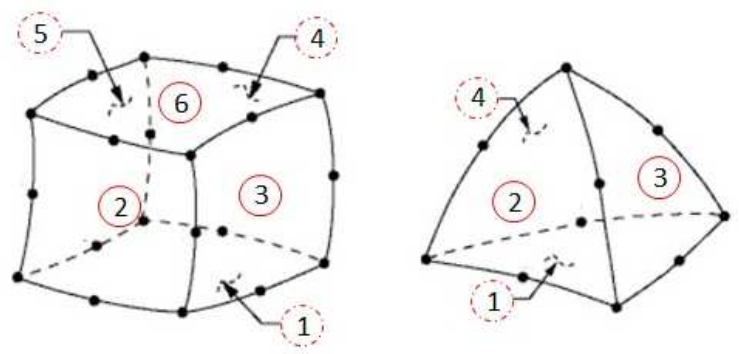

Fig. 7. Different types of mesh elements: SOLID186 (left), SOLID187 (right); 1-6 - refer to wall numbers

First calculations of the considered component have been performed with default mesh parameters in order to find the most straightened areas. The created model was composed of 10746 nodes and 5316 tetrahedral elements. The Relevance parameter values were differentiated between -100 and 100 . The smallest negative values require large elements whereas bigger positive values of Relevance parameter assure more accurate mesh . Computation has been realized with the default element size coefficient: 0 (Fig. 8) whereas subsequent analyses have been carried out for the value of coefficient equal 50 .

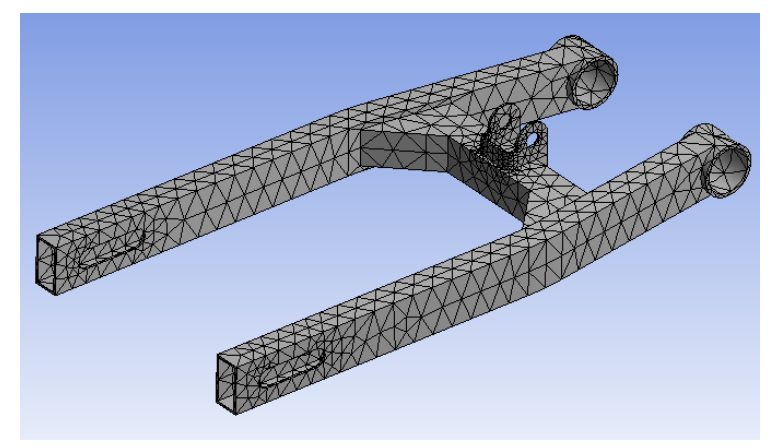

Fig. 8. Finite element mesh of suspension arm model (default system settings) 
Since regular, cubic meshes are mainly used for simple geometries, the common engineering practice is to divide the basic body into smaller pieces with easier geometries. Every singular elements of the structure are meshed and finally they are joined in one complete component. Such an approach has been also used during meshing the most deformed regions (Fig. 9).

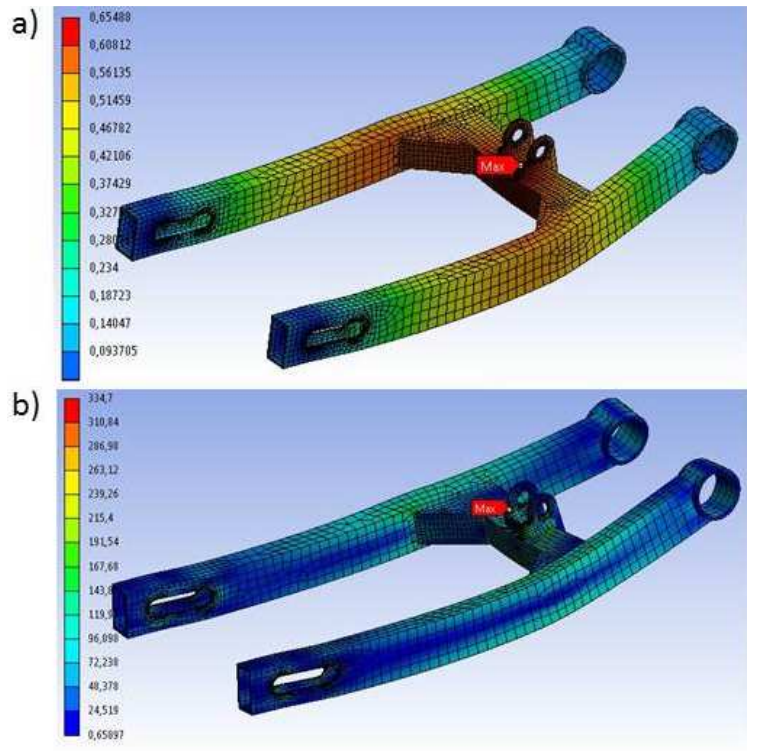

Fig. 9. Distributions of (a) strain (in $\mathrm{mm}$ ) and (b) stress (in $\mathrm{MPa}$ )

To illustrate the distributions of strains and stresses the von Misses criterion was selected. In the case of final calculations the model has been meshed with hexagonal elements with some local mesh refinement. The element size and desired elements number, and the Sphere of Influence feature have been adequately optimized. Furthermore, an assumption of maximal 5\% difference in average stress value (Elemental Mean type) among four neighbouring mesh elements has been established as the quality indicator. This should help to determine proper stress and strain distribution between the closest mesh elements. The obtained results were satisfying.

Summarizing, final mesh structure consists of 60000 nodes and over 18500 elements (5316 for default system settings). Figures 9 and 10 illustrate distributions of strains and stresses. The performed analyses showed that mean stress value (according to Huber von Misses criterion) did not exceed $70 \mathrm{MPa}$. In the areas of stress concentration the values of stresses were between 80 and 120 MPa. Maximal stress (slightly above $200 \mathrm{MPa}$ ) has been noticed close to radius of the shock absorber holder. Small radius causes stress concentration and may lead to cracks in material. Maximal strain value has been also observed within strut area $(0.65 \mathrm{~mm})$. 


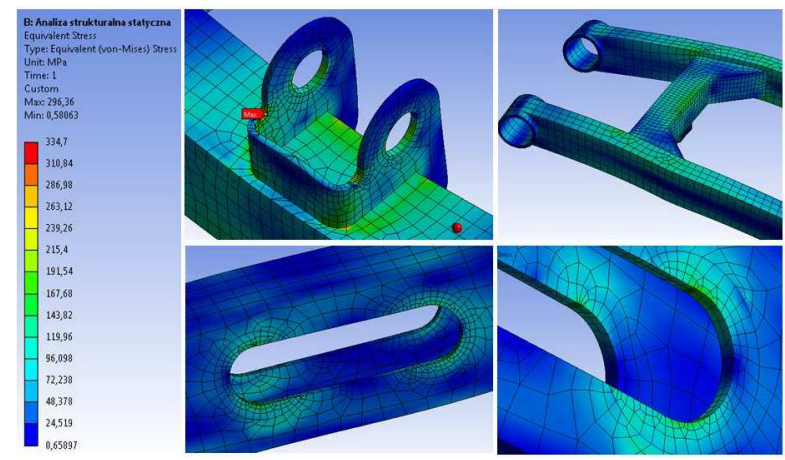

Fig. 10. The most loaded areas of suspension arm (MPa)

For defined boundary conditions, applied loads and mesh type the modal analysis has been carried out. Vibrations are understood as mechanical phenomenon of structure that oscillates around an equilibrium point. Frequency at which the structure tends to oscillate when it is not excited by any external force is its natural frequency [8]. In most engineering cases vibrations are not desired. They cause energy dispersion and generate noise. If the value of forced frequency (caused by influence of applied force) is close to or equals the natural structure frequency, a resonance phenomenon can be observed. It directly increases vibrations amplitude and thus it can result in destruction of component. Therefore, both usage of resilient materials and the proper geometrical design can prevent many components against negative vibrations influence. As a result, one of the basic engineering aim is to design components that both meet strength requirements and are resilient enough to avoid covering the free component frequencies with typical external extortion.

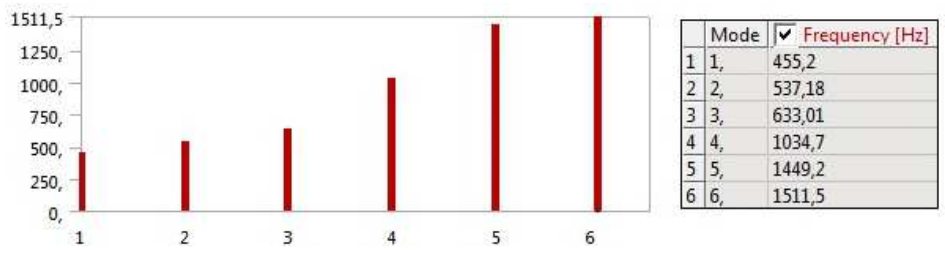

Fig. 11. First six free vibrations frequencies of the component

Engineering practice shows that the most important are the lowest frequencies and therefore first six modes were considered (Fig. 11). As a result, besides critical frequencies some suitable strain modes of the component could be observed (Fig. 12). It also allows to identify the areas of largest deformation. 


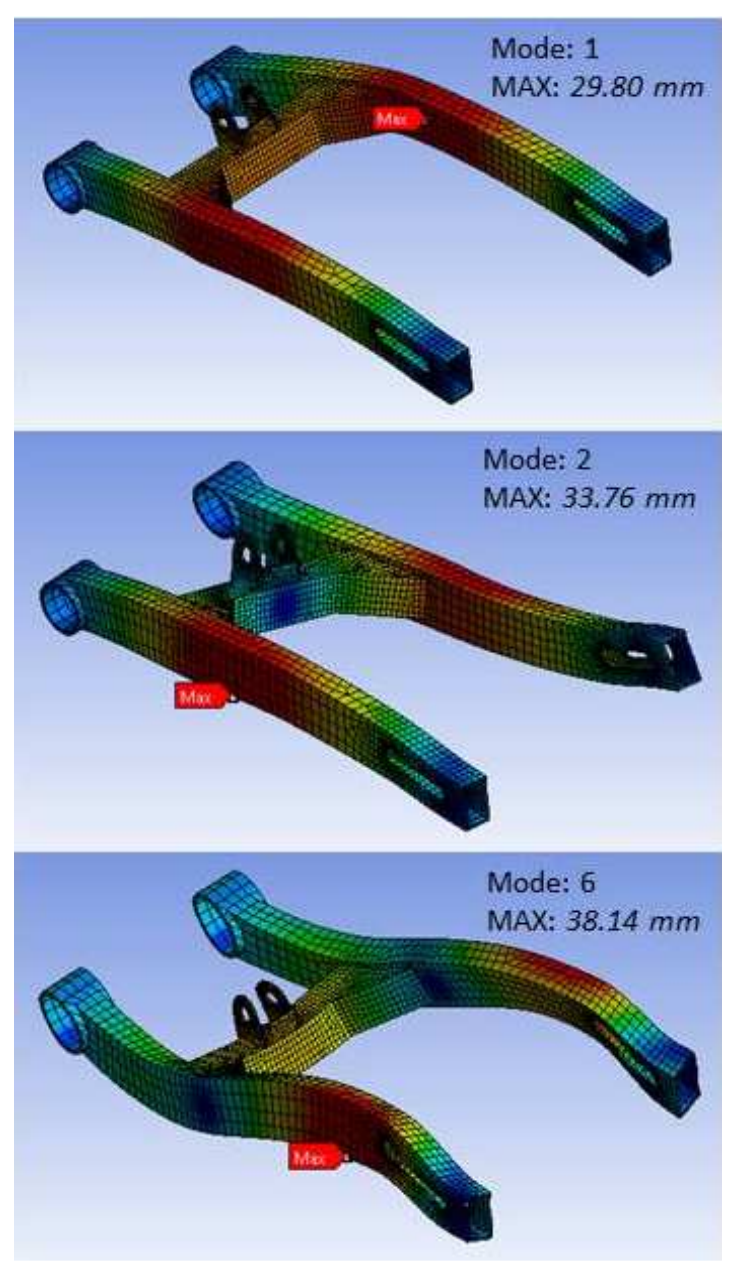

Fig. 12. Three selected free vibration modes: $1^{\text {st }}$ (top), $2^{\text {nd }}$ (middle), $6^{\text {th }}$ (bottom), deformations not to scale

The possibility to modify component's geometry after a series of performed calculations seems to be a great advantage of ANSYS Workbench. For that purpose a set of tools within Design Modeller mode has been dedicated. The tools of ANSYS Workbench support the review of the results and help to determine stress/strain distribution in analysed regions.

\section{Summary}

This results presented in the article proves that modern CAD/CAE systems truly support both manufacturing and design processes. Components and whole structures can be optimized at any stage of their exploitation. A few design con- 
cepts at once can be easily analysed. The systems ensure good products quality and balance their price simultaneously.

The results of the performed analyses point out that considered component meets static strength requirements for the assumed load conditions. It would be desired to decrease the stress concentration in transient radius of suspension arm. Similarly, walls thickening at the ends of lugs eliminates stress concentration. Modal analysis allowed to determine the first six vibration modes and the critical frequencies. To make the component analyses complete, further analyses with dynamic loadings and some fatigue and life trials (weld joints considered as well) should be performed. Therefore, these problems will be scope of a next study.

\section{References}

[1] Bąk R., Burczyński T.: Wytrzymałość materiałów z elementami ujęcia komputerowego, WNT, Warszawa 2009.

[2] Gmurczyk G., Reymer P., Kurdelski M.: Global FEM model of combat helicopter, J. KONES Powertrain Transport, 18 (2011) 137-144.

[3] Jaskulski A.: CAD/CAE - Przewidywane kierunki rozwoju, Mechanik, 87 (2014) 958-959.

[4] Jerry J., Kuric I., Grozan S., Cecuan V.: Calibration of 5-axis CNC machine tool with 3D quick set measurement system, Academic J. Manuf. Eng., 12 (2014) 20-25.

[5] Kordowska M.: Wykorzystanie systemów CAD/CAM w procesie projektowania na potrzeby przemysłu samochodowego, Autobusy, 12 (2011) 199-203.

[6] Kosiuczenko K., Napadlek M.: Numerical simulation the finite element method (FEM) of stress and strain for the chosen coatings TBCs on turbine blades loaded with laser impulses, J. KONES Powertrain Transport, 19, (2012) 183-186.

[7] Kułakowska A., Patyk R.: Obliczenia numeryczne trwałości układu korbowo-tłokowego silnika spalinowego, Autobusy, 12 (2011) 253-258.

[8] Łaszek S.: Przykłady analizy konstrukcji w systemie MES ANSYS-Workbench, vol. 12.1, Wydawnictwo PK, Kraków 2012.

[9] Rakowski G., Kacprzyk Z.: Metoda Elementów Skończonych w mechanice konstrukcji, Oficyna Wydawnicza Politechniki Warszawskiej, Warszawa 2005.

[10] Skrzat A.: Modelowanie liniowych i nieliniowych problemów mechaniki ciała stałego i przepływów ciepła w programie ANSYS Workbench, Oficyna Wydawnicza Politechniki Rzeszowskiej, Rzeszów 2014.

[11] ANSYS Workbench, User Manual Guide. 


\section{ANALIZA WYBRANEGO KOMPONENTU ZAWIESZENIA \\ MOTOCYKLA Z WYKORZYSTANIEM MODELOWANIA CAD \\ ORAZ METODY ELEMENTÓW SKOŃCZONYCH}

\section{Streszczenie}

W artykule przedstawiono procedurę modelowania oraz analizę strukturalną i modalną elementu zawieszenia motoroweru. Do zamodelowania komponentu użyto programu Siemens NX 8.5, natomiast analizy numeryczne przeprowadzone zostały w systemie ANSYS Workbench z wykorzystaniem Metody Elementów Skończonych (MES). Zachowanie części odpowiadające warunkom jej pracy odzwierciedlono definiując stosowne obciążenia, warunki brzegowe i założenia konstrukcyjne. Rezultatem wykonanych analiz są rozkłady naprężeń, odkształceń i wybranych postaci drgań własnych komponentu. W oparciu o wyniki sformułowano wnioski oraz zaproponowano kierunki dalszych badań.

Słowa kluczowe: CAD, CAE, analiza strukturalna, analiza modalna, metoda elementów skończonych

DOI: $10.7862 / \mathrm{rm} .2017 .12$

Otrzymano/received: 31.03 .2017

Zaakceptowano/accepted: 14.06 .2017 